\title{
Comparative study of egg contamination with Salmonella Heidelberg and Salmonella Typhimurium
}

\author{
Estudo comparativo da contaminação de ovos com Salmonella \\ Heidelberg e Salmonella Typhimurium
}

\author{
Germana Vizzotto Osowski ${ }^{*}$ (D); Lana Flávia Baron²; Arlei Coldebella ${ }^{3}$; Francisco Noé Fonseca \\ Sandra Camile Almeida Mota ${ }^{3}$; Roberto Degenhardt ${ }^{4}$; Sabrina Castilho Duarte ${ }^{3}$
}

\author{
${ }^{1}$ Universidade de São Paulo, Faculdade de Medicina Veterinária e Zootecnia, Programa de Pós-graduação em Epidemiologia Experimental \\ Aplicada às Zoonoses, São Paulo - SP, Brazil \\ ${ }^{2}$ Universidade do Contestado, Campus Concórdia, Salete - SC, Brazil \\ ${ }^{3}$ Embrapa Suínos e Aves, Distrito de Tamanduá, Concórdia - SC, Brazil \\ ${ }^{4}$ Universidade do Oeste de Santa Catarina, Campus Joaçaba, Joaçaba - SC, Brazil
}

\begin{abstract}
Cases of salmonellosis in humans have been associated with consumption of eggs contaminated with this bacterial pathogen due to insufficient heat treatment. The most prevalent serotypes of Salmonella in Brazil include serotypes Enteritidis, Typhimurium, and Heidelberg. The first two serotypes are major causes for eggs to be withheld from sale and for recalls over Salmonella contamination concerns in both domestic and foreign markets. Eggs may be contaminated through transovarian infection (transovarial transmission) due to the presence of the microorganism in the hen's oviduct and bacterial penetration of the eggshell. There is little data in the literature on the susceptibility of egg contamination and eggshell penetration by Brazilian serotypes of Salmonella. The present study aimed to evaluate the ability of S. Heidelberg and $S$. Typhimurium serotypes to penetrate through the eggshell and detect these bacteria in the albumen and yolk according to the thickness of the eggshell. SPF (specific-pathogen-free) eggs were artificially contaminated by contact with moist cotton containing Salmonella $\left(15 \times 10^{8} \mathrm{CFU} / \mathrm{ml}\right)$. Eggs were divided into the following groups: negative control (not contaminated), S. Heidelberg, and $S$. Typhimurium. Subsequently, these eggs were incubated at $37^{\circ} \mathrm{C}$, and their contents analyzed after $4 \mathrm{~h}$ and $24 \mathrm{~h}$ of incubation. The evaluation (assessment) of the contamination was performed by traditional bacteriology and confirmed by biochemical and serological tests. Treatments were compared with Fisher's test using a SAS statistical software. For S. Heidelberg, the percentage of positivity (positive cases) was lower in both albumen and yolk at $4 \mathrm{~h}$ and $24 \mathrm{~h}$ intervals (33.33\% and 3.7\%, and 3.7\% and 3.7\%, respectively) compared to S. Typhimurium $(26.63 \%$ and $7.41 \%$, and $33.33 \%$ and $33.33 \%$, respectively). These findings suggest that the former strain (S. Heidelberg) was unable to survive in the hostile environment of the albumen. In contrast, eggshell thickness had no significant correlation with the number of positive samples. In conclusion, the results obtained in the egg infection model show that the Salmonella strains tested were able to penetrate the eggshell and multiply in both the albumen and yolk and that $S$. Typhimurium proved to be the most efficient to grow within these portions of the egg.
\end{abstract}

Keywords: Eggshell penetration. Poultry. Food safety. Public health. Microbial survival.

\section{RESUMO}

Salmonelose em humanos é frequentemente associada ao consumo de ovos contaminados sem o devido processamento térmico. No Brasil, os sorotipos mais prevalentes são: Enteritidis, Typhimurium e Heidelberg, alvo de barreiras sanitárias na comercialização de ovos. O ovo pode ser contaminado por via transovariana, pela presença da bactéria no oviduto da ave e também por penetração da bactéria através da casca do ovo. Existem poucas informações acerca da capacidade de contaminação no ovo por sorotipos isolados no Brasil. Este estudo teve como objetivo avaliar a capacidade dos sorotipos $S$. Heidelberg e $S$. Typhimurium penetrar através da casca do ovo e colonizar a albumina e gema, relacionando à espessura da casca. Os ovos SPF (livres de patógenos específicos) foram contaminados artificialmente pelo contato com algodão umedecido $\left(15 \times 10^{8} \mathrm{CF} / \mathrm{mL}\right)$. Os ovos foram divididos nos seguintes grupos: controle negativo (sem contaminação), $S$. Heidelberg e $S$. Typhimurium. Posteriormente foram incubadas a $37^{\circ} \mathrm{C}$ e seu conteúdo foi analisado após 4 e $24 \mathrm{~h}$. A avaliação da contaminação foi realizada por bacteriologia tradicional e confirmada por testes bioquímicos e sorológicos. Os tratamentos foram comparados com o teste de Fisher usando o software estatístico SAS. Para S. Heidelberg, a 
percentagem de positividade foi menor no albúmen e gema às 4 e $24 \mathrm{~h}(33,33 \%$ e 3,7\%, 3,7\% e 3,7\%, respectivamente) em comparação com $S$. Typhimurium $(26,63 \%$ e $7,41 \%, 33,33 \%$ e $33,33 \%$, respectivamente), sugerindo que a primeira estirpe foi mais vulnerável as condições hostis da albumina. Por outro lado, a espessura da casca do ovo não teve relação significativa com a positividade das amostras. Em conclusão, o modelo de infecção do ovo mostrou que as cepas foram capazes de penetrar a casca do ovo e sobreviver na albumina e gema, sendo que o sorotipo $S$. Typhimurium foi mais eficiente.

Palavras-chave: Penetração de casca de ovo. Aves de postura. Segurança alimentar. Saúde pública.

\section{Correspondence to:}

Germana Vizzotto Osowski

Universidade de São Paulo, Faculdade de Medicina

Veterinária e Zootecnia

Avenida Prof. Almeida Prado, 1280, Butantã

CEP: 05508-900, São Paulo - SP, Brazil

e-mail: germanav.osowski@gmail.com

Submited: September 21, 2018

Approved: January 16, 2019

How to cite: Osowski GV, Baron LF, Coldebella A, Fonseca FN, Mota SCA, Dagenhardt R, Duarte SC. Comparative study of egg contamination with Salmonella Heidelberg and Salmonella Typhimurium. Braz J Vet Res Anim Sci. 2019;56(1):e150479. https://doi.org/10.11606/issn.16784456.bjvras.2019.150479.

\section{Introduction}

According to the Brazilian Association of Animal Protein (BPA), in 2017, Brazil achieved the highest rate of egg consumption recorded to date. Egg production reached 39.9 billion units, $99.74 \%$ of which were destined for the domestic market and only $0.26 \%$ was exported (Associação Brasileira de Proteína Animal, 2018). Although statistics for hen egg production can vary greatly depending on the source, of approximately 69.7 million metric tons of eggs produced worldwide in 2014, South America produced 4.7 million metric tons (about 6.75\%). Among the top 20 countries for egg production in 2013, Brazil ranked 7th (Conmay, 2015). Brazilian companies account for 2 of the 25 largest egg producers worldwide when ranked by size of layer flock (Clements, 2015).

As a result of high demand for egg production in Brazil, concern over the incidence of some bacterial pathogens e.g. Salmonella has increased. Poultry and poultry products have accounted for 54\% of Salmonella (Gould et al., 2013; Jackson et al., 2013; Painter et al., 2013). The intestinal tract of humans and animals are the main natural sources of this microorganism. Diseases caused by Salmonella spp. are often associated with raw foodstuffs of animal and avian origin such as meat, eggs, and dairy products, and outbreaks of Salmonella in association with fresh produce accounted for approximately $50 \%$ of the total (Strawn et al.,
2014). Salmonellosis is currently considered one of the most significant public health concerns worldwide (Cardoso \& Carvalho, 2006).

In Brazil, the most prevalent avian serotypes are Enteritidis, Typhimurium, and Heidelberg (Back, 2004). Although $S$. Enteritidis is the food-borne pathogen reported most often in the literature in outbreaks in humans that eat contaminated food, attention should be drawn to $S$. Typhimurium and $S$. Heidelberg as well, since these strains have been responsible for reducing or stopping egg sales due to the risk they pose to public health. Furthermore, eggs for export have been regularly monitored for the presence of Salmonella serotypes that have an impact on public Health, such as $S$. Heidelberg and $S$. Typhimurium. Despite technological advances and industrial modernization, bacterial contamination of eggs still occurs, especially by Salmonella.

In more recent times, $S$. enterica serovar Heidelberg has emerged as a leading food-borne disease-causing serovar (Ricke \& Gast, 2016). Egg consumption has been identified as a risk factor for $S$. Heidelberg infection (Foley et al., 2011; Reddy et al., 2016). Hennessy et al. (2004) estimated that approximately $37 \%$ of $S$. Heidelberg population-attributable infections originate from consuming eggs. Due to the occurrence of $S$. Heidelberg in poultry houses, poultry could be considered as a primary source of the pathogen, thus making poultry associated $S$. Heidelberg a potential public health concern (Food and Drug Administration, 2012).

S. enterica serovar Typhimurium has been identified as a source of often egg-transmitted disease in Australia (Gole et al., 2014). The serovar $S$. Typhimurium is commonly isolated from Australian layer farms (Cuttell et al., 2014; New South Wales, 2015). To date, $S$. Typhimurium has been the most frequently reported serovar during egg product-related food poisoning outbreaks Australia-wide (The OzFoodNet Working Group, 2002, 2003, 2005, 2006, 2012). During this period, eggs or consumption of raw egg-based foods were frequently implicated as the source of infection (Thomas et al., 2006).

Eggs contaminated with Salmonella spp. represent a significant risk in the transmission of bacterial diseases to consumers. The exact mechanism by which eggs become 
contaminated by Salmonella spp. is unclear. The cuticle is the egg's first defense against bacteria. In the first few minutes after oviposition, the cuticle is usually moist and immature, and is therefore less effective at preventing microorganism penetration, as shown by previous research conducted by Sparks \& Board (1985), Padron (1990), and Miyamoto et al. (1997). In addition, since the egg is warmer $\left(42^{\circ} \mathrm{C}\right.$ is the hen's body temperature) than the environment, subsequent cooling causes contraction of the egg contentes, which creates negative pressure and easily pulls the bacteria through the eggshell and its membranes (Bruce \& Drysdale, 1994).

The egg has a protective mechanism that includes a diversity of antimicrobials, including highly effective physical and microbicide barriers. Egg yolk provides abundant nutrients to support rapid and prolific microbial growth at warm temperatures (Gurtler \& Conner, 2009), but albumen contains proteins that limit iron availability and disrupt bacterial membranes (Baron et al., 2016). Although Salmonella spp. is most commonly deposited either in the albumen or on the outside surface of the vitelline (yolk) membrane of contaminated eggs, it can rapidly migrate across this membrane to reach the nutrient-dense interior contents of the yolk at warm temperatures (Gast \& Holt, 2001; Gast et al., 2003, 2010). Still refrigeration temperatures can reduce or prevent both Salmonella multiplication in egg yolks (Gast \& Holt, 2000; Gurtler \& Conner, 2009) and penetration of vitelline membranes (Gast et al., 2006, 2007), Salmonella spp. can survive and replicate in eggshells and egg contents even under low temperature and humidity (Messens et al., 2006).

It is also speculated that flagella could be an important factor for moving Salmonella through albumen and toward the yolk (Baron et al., 1997). In addition to motility, curli fimbriae production appears to be important for invasion and survival within egg contents (Cogan et al., 2004).

Salmonella can contaminate eggs in two distinct ways, either by external penetration of the eggshell or internally via transovarian infection (Gantois et al., 2009; Howard et al., 2012; Martelli \& Davies, 2012). The external eggshell penetration route includes transmission from the feces of colonized birds to the egg surface followed by penetration to the interior of eggs and growth during the storage (Cockburn \& Vemon, 1956). S. Heidelberg would appear to be a candidate for external egg contamination, as it has been isolated from layer feces in commercial layer houses (Li et al., 2007).

There is little data in the literature on the contamination ability of the Salmonella serotypes isolated in Brazil, which warrants further investigations. Additional research should be carried out in order to elucidate the ability of eggshell penetration by Salmonella spp. and other serotypes that pose a significant threat to public health.

Salmonella contamination is often widely distributed throughout laying houses in association with dust and feces. Common factors that increase such risk include animal husbandry and poultry management, hygiene standards, biosafety measures, food contamination levels, socio-environmental, and environmental factors (Garber et al., 2003; Im et al., 2015; Kinde et al., 2005), and can be perpetuated and amplified by severe rodent or insect infestations to levels capable of surviving standard cleaning and disinfection methods (Carrique-Mas et al., 2009; Lapuz et al., 2012; Snow et al., 2010; Wallner-Pendleton et al., 2014). In addition, considering the range of new emerging serotypes of this bacterial pathogen, ensuring egg quality has become a major issue to the poultry industry (De Reu et al., 2006).

Commercial egg production facilities represent highly complex environments, so the potential influences on the presence of food-borne pathogens in egg-producing flocks are correspondingly diverse. The most commonly identified risk factors linked to increased Salmonella prevalence in egg-laying chickens are larger flock size, greater flock age, housing in older facilities, and multiple-age stocking (Denagamage et al., 2015; Huneau-Salaün et al., 2009; Mollenhorst et al., 2005; Namata et al., 2008; Pitesky et al., 2013; Snow et al., 2010; Van Hoorebeke et al., 2010).

In addition, in some commercial settings, eggs are produced in poultry farms with inadequate hygiene conditions. Hence, eggs with poor quality shell (defects, cracks, dirt, or thin shell) may be mixed with a batch of good quality eggs, since these cracks are not always detected in the production plant. The prevalent conditions of these eggs facilitate the migration of Salmonella spp. from the surface into the internal egg structures, thus increasing the risk of bacterial contamination (Oliveira \& Silva, 2000).

Penetration of bacteria through the eggshell is directly influenced by the quality and thickness of the eggshell (De Reu et al., 2006; Schoeni et al., 1995), which can be affected by several factors, including the bird's age (due to the lower deposition of calcium), genetics, feeding, stress, and room temperature. Although moisture facilitates penetration of bacteria in the eggshell (Berrang et al., 1999; Bruce \& Drysdale, 1994), the presence of moisture is not necessary for egg contamination to occur (Padron, 1990).

Furthermore, the ability of Salmonella to penetrate through eggshells may vary among strains (serotypes). In this context, the present research project was designed to investigate the ability of different serotypes of Salmonella spp. 
to penetrate eggs. This study aimed at evaluating the ability of $S$. Heidelberg and $S$. Typhimurium to penetrate the eggshell in vitro and to determine their dissemination profile within the albumen and the yolk, as well as to correlate this ability with eggshell thickness.

\section{Material and Methods}

\section{Experimental design}

The samples tested included freshly laid eggs (early morning collection) that were not subjected to any cleaning process and originated from White Leghorn chickens between 45 to 60 weeks of age that were raised at the Embrapa Swine and Poultry Research Center in south Brazil under specific-pathogen-free (SPF) conditions.

A total of 120 eggs were divided into 3 groups as follows: negative control (without artificial contamination, $\mathrm{n}=12$ in total, 6 eggs for each Salmonella strain); eggs contaminated with $S$. Heidelberg ( $\mathrm{n}=54$ eggs; 27 eggs for each timespan, i.e. $4 \mathrm{~h}$ and $24 \mathrm{~h}$ ), and $S$. Typhimurium ( $\mathrm{n}=27$ eggs; 27 eggs for each timespan, $4 \mathrm{~h}$ and $24 \mathrm{~h}$ ).

The bacterial isolates used in the study were strains of $S$. Enterica serotype Heidelberg and Typhimurium isolated in Brazil. These bacteria were isolated from artificially inoculated birds from an in vivo experiment carried out at the EMBRAPA Swine and Poultry Research Center.

\section{Inoculum preparation}

In order to prepare the inoculum, $20 \mu \mathrm{l}$ of the $\mathrm{BHI}$ culture (Brain Heart Infusion / Sigma, 20\% glycerol) of S. Heidelberg (Bacterioteca 19366) and S. Typhimurium (Bacterioteca 19540) were transferred into a nonselective TSA medium (Tryptone Soya Agar/Oxoid) and BG (Bright Green/Sigma) with novobiocin ( $40 \mathrm{mg} / \mathrm{L}$ ), and into a selective XLT4 medium (Xylose, Lysine/Difco; Tergitol 4 / Remel) in order to assess if the samples remained pure followed by incubation at $37^{\circ} \mathrm{C}$ for $24 \mathrm{~h}$.

Then the bacterial colonies from the TSA medium were added in $5 \mathrm{ml}$ of BHI broth and their degree of turbidity adjusted (calibrated) according to tube 5 of the McFarland scale $\left(15 \times 10^{8} \mathrm{CFU} / \mathrm{mL}\right)$. Eggs were carefully handled in order to prevent (avoid) the removal of the outer cuticle.

\section{Preparation and exoerimental contamination of eggs}

Eggs were transported at room temperature to our local laboratory where they were examined by candling to determine if the shell had any crack that would serve as an entry portal for Salmonella.
Eggs that had internal or external cracks were discarded. An egg box coated with foil and cotton discs was put inside the carton cavities. After approximately $30 \mathrm{~min}$ of collection, $2 \mathrm{ml}$ of the inoculum was added to the cotton, and eggs were placed on it with the air chamber facing up the eggs. The box was immediately incubated for $4 \mathrm{~h}$ and $24 \mathrm{~h}$ at $37^{\circ} \mathrm{C}$ in a bacteriological incubator (Lab-Line Instruments).

\section{Collection of contents and eggshell}

After disinfecting the upper part of the eggs with 70\% alcohol, these specimens were aseptically opened, and the shell was separated from the internal contents (yolk/albumen).

The albumen was collected with individual yolk spoons that were sterilized with hypochlorite followed by UV exposure. To avoid yolk contamination, its content was harvested with a syringe. Samples were then homogenized (Stomacher ${ }^{\circledR} 400$ Ciculator) for $30 \mathrm{~s} / 230 \mathrm{rpm}$ and pre-enriched with BHI $(1: 9, w / v)$ for later incubation in glass flasks at $37^{\circ} \mathrm{C}$ for $24 \mathrm{~h}$.

The thickness of the lower portion of the shell was measured using a micrometer (Mitutoyo) that was in contact with the contaminated substrate, and 2-3 measurements of different sites were performed.

\section{Bacterial isolation}

After pre-enrichment, samples were subjected to selective enrichment in tetrathionate broth (Sigma) and Rappaport Vassiliadis broth (Fluka). For this purpose, $100 \mu \mathrm{l}$ of the pre-enriched culture was transferred into test tubes containing $9.9 \mathrm{ml}$ of Rappaport Vassiliadis broth and into $1 \mathrm{ml}$ test tubes containing $9 \mathrm{ml}$ of Tetrathionate broth with iodine-iodide and BG. Samples were incubated at $42^{\circ} \mathrm{C}$ for $18 \mathrm{~h}$ to $24 \mathrm{~h}$.

After incubation, isolation and identification of colonies were carried out; $20 \mu \mathrm{L}$ of the culture was seeded in petri dishes containing XLT4 agar and BG agar. Petri dishes were then incubated at $37^{\circ} \mathrm{C}$ for $48 \mathrm{~h}$.

In terms of the morphological characteristics of the bacterial colonies, those colonies with a pink halo and reddish halo on BG agar and those colorless colonies with a central black spot on XLT4 agar were considered positive.

Colony Forming Units (CFU) with typical morophological features were selected ( 1 per dish) and transferred into TSA (tryptic soybean agar) for biochemical screening and antigenic identification.

For the biochemical screening, a SIM medium (sulfide-indole motility / Merck), indol (Kovac's Reagent), TSI (triple sugar iron agar / Merck), LIA (lysine-iron agar / Merck), urea broth (Micromed), and 
ONGP broth (2 nitrophenyl-D-galactapyramose / Colilert test) were used. Tubes were incubated at $37^{\circ} \mathrm{C}$ for $24 \mathrm{~h}$. For the antigenic identification, serology was carried out by the agglutination technique, and a polyvalent serum was used.

\section{Statistical Analysis}

Odds ratio calculation (serotype in conjunction with time of contamination) and eggshell thickness with the presence of Salmonella in each egg component (albumen and yolk) were evaluated by exact logistic regression analysis using the LOGISTIC procedure of SAS statistical software (SAS Institute Inc., 2012). The differences were considered significant when $\mathrm{p}<0.05$. The influence of the eggshell thickness on the presence of Salmonella was analyzed by using the odds ratio calculation. For the treatment effect, median percentages of Salmonella detection and the respective. Wald test were presented by comparing the treatments two to two.

\section{Results and Discussion}

$S$. Heidelberg and $S$. Typhimurium strains were isolated from the yolk and albumen removed from the contaminated eggs. Analysis using Fisher's exact test showed a significant Salmonella growth $(\mathrm{p}<0.05)$ in the albumen and yolk in comparison to the negative control. In the analyses performed in this study, $S$. Typhimurium presented a higher frequency of contamination in the albumen compared to $S$. Heidelberg in the $24 \mathrm{~h}$ group (Figure 1). Our results corroborate with those of Gast et al. (2005) after inoculation on the outer surfaces of the egg yolk membranes, as all strains of $S$. Heidelberg were able to penetrate into the inner yolk content after $24 \mathrm{~h}$ of incubation.
In both time intervals evaluated in the present study ( $4 \mathrm{~h}$ and $24 \mathrm{~h}$ ), the albumen presented a higher frequency of contamination in comparison to the yolk. Our findings are not in accordance with those of the study published by Humphrey et al. (1991). The albumen is more frequently contaminated with Salmonella than the yolk, as observed in our study. This finding highlights the importance of preventing Salmonella contamination in poultry farms from external sources other than the chicken itself, since albumen, in particular, is used in dessert preparation without any heat treatment, thus posing a significant risk to human health.

After $4 \mathrm{~h}$ of incubation, it was possible to observe contamination in the eggs by Salmonella.This finding demonstrates that contamination may occur within few hours after exposure to a contaminated environment such as chicken farms with poor or inadequate biosecurity measures. Similar results were observed by Raghiante et al. (2010). These authors detected Salmonella $4 \mathrm{~h}$ after the egg was in contact with a contaminated substrate. Other studies have also found that external contamination of eggs with different Salmonella serotypes can occur after $24 \mathrm{~h}$ of contact (Schoeni et al., 1995; Oliveira \& Silva, 2000).

Eggshell penetration by $S$. Typhimurium can be influenced by various eggshell ultrastructural features including cap quality, alignment, erosion, confluence, Type B bodies, and cuticle cover. Hughey \& Johnson (1987) showed that lysozyme does not inhibit the growth of $S$. Typhimurium and of several other gram-negative bactéria, which explains the presence of Salmonella in the albumen and the differences in the prevalences between serotypes observed in this study.

In our study, $S$. Heidelberg presented lower survival ability in the hostile conditions of egg albumen compared

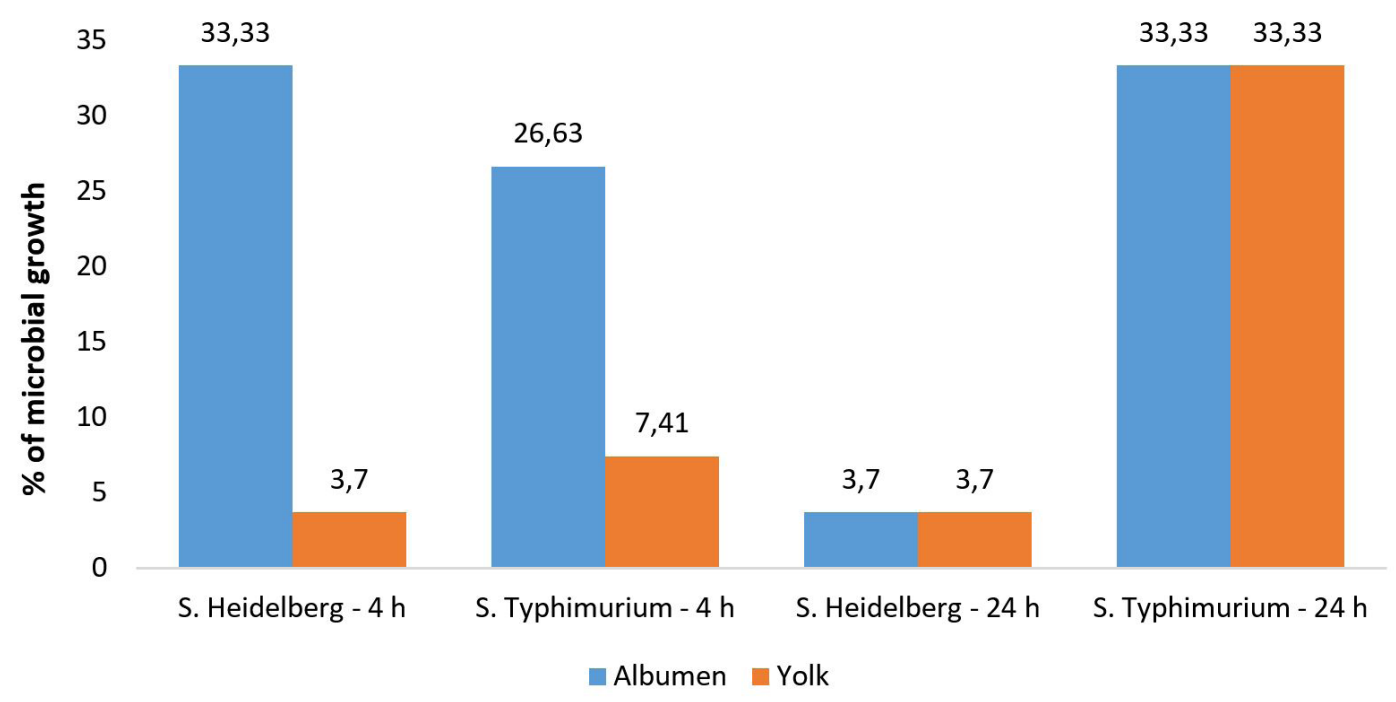

Figure 1 - Positive percentage of Albumen and Yolk for Salmonella versus Serotype and time of contamination. Percentages followed by distinct letters differ significantly by the Wald test $(\mathrm{p} \leq 0.05)$ for egg component 
to $S$. Typhimurium. This difference in the egg penetration ability of the strains analyzed in the present study may be related to virulence mechanisms developed by the bacterial strains that occur in Brazil. Although it remains to be determined if similar criteria would be applicable for $S$. Heidelberg in eggs, there may be potential for a relatively high prevalence of $S$. Heidelberg in eggs if the opportunity for initial contamination arises and sufficient temperature abuse occurs to allow substantial growth.

Certainly, improper transport and a break in the cold chain could enhance growth of $S$. Heidelberg in contaminated eggs (Schoeni et al., 1995). Although pasteurizing egg whites appears to cause a greater than 8-log reduction of $S$. Heidelberg (Muriana, 1997), cooking may not be able to always eliminate the organismo, since several Salmonella serovars are capable of surviving simulated domestic conditions for various forms of cooking eggs (Humphrey et al., 1989).

Others have compared the growth of different Salmonella serovars by artificially contaminating egg albumen and reported no differences between $S$. Enteritidis $(\mathrm{n}=8)$ and $S$. Typhimurium $(\mathrm{n}=24)$ at $37^{\circ} \mathrm{C}$ or $42^{\circ} \mathrm{C}$ (Guan et al., 2006). Similarly, Messens et al. (2004) did not observe any growth advantage for $S$. Enteritidis in egg albumen when compared with other non-S. Enteritidis serovars including S. Typhimurium, Senftenberg, Stanleyville, Mbandaka, and Blockley (Messens et al., 2004). This suggests a similarity between the serotype $S$. Enteritidis and S. Typhimurium.

Since there is a lack of information regarding the Brazilian strains of Salmonella, the present research proposal was designed. This study aimed at evaluating bacterial samples from poultry farms documented by the Embrapa Swine and Poultry Research Center. For the safest and most reliable evaluation of the invasion ability of Salmonella on eggs, we had to simulate a field contamination scenario in a laboratory environment.

Schoeni et al. (1995) reported that $S$. Typhimurium levels may increase when the egg is kept at higher temperatures, e.g. $25^{\circ} \mathrm{C}$. These authors concluded that eggs should be kept at $4^{\circ} \mathrm{C}$ in order to prevent bacterial growth inside eggs. In our study, all analyses were carried out using a temperature of $37^{\circ} \mathrm{C}$ (temperature for isolation of Salmonella spp.), aiming to standardize the temperature with different intervals of exposure under the same conditions. Our findings indicate that exposure time is a significant factor in the presence of Salmonella. It is important to note that egg penetration studies were performed after infecting eggs with Salmonella in laboratory conditions followed by incubation at room temperature (Gole et al., 2014). Salmonella penetration across the eggshell, however, is low at refrigeration temperature $\left(4^{\circ} \mathrm{C}\right)$ (Chousalkar et al., 2010), underscoring the importance of proper egg storage in both commercial and domestic environments.

Shell thickness of all eggs used in this study was measured, ranging from $51 \mu \mathrm{m}$ to $97 \mu \mathrm{m}$. No significant correlation was observed between eggshell thickness and the presence of Salmonella in eggs. Our findings differ from those obtained by Ray et al. (2015). Those authors demonstrated that a decrease in the eggshell thickness facilitated the entry of Salmonella into the egg (yolk/albumen). However, Williams et al. (1968) also noted that eggshell thickness did not have a significant influence on bacterial penetration, though the prescence of eggshell cuticle plugs are more important.Also of interest was the finding that bacterial motility is related to the ability of the bacteria to penetrate the eggshell. One study showed that inactivation of agfA (encoding curli production) invaded yolks less frequently, suggesting the importance of the role of curli in survival and persistence within the egg (Cogan et al., 2004). In addition, genes involved in DNA replication and repair have been identified in multiple studies. In one study, disruption of yafD (a member of exonuclease endonuclease-phosphatase family) was reported to significantly impact the growth of $S$. Enteritidis and $S$. Typhimurium within egg albumen (Lu et al., 2003).

According to Board et al. (1979), the removal of the cuticle by abrasion of the eggshell or by chemical treatment increases the probability of bacterial penetration through the eggshell. Thus, in the present study, eggs were not washed in order to avoid cuticle damage, since the presence of cracks would facilite bacterial penetration. Egg assessment and selection by candling were also important in our study, as this procedure allowed us to remove and discard cracked, damaged, or dirty eggs. There are reports in the literature that cracked and dirty eggs are significantly more susceptible to contamination by Salmonella spp. (Poppe et al., 1997; Todd, 1996). In addition, the selected eggs were from birds of the same genetic strain and aged between 45 and 60 weeks (the usual age of laying farm birds), so that they did not have a significant difference in the quality and thickness of the shell.

\section{Conclusion}

The results of the present study show that both Brazilian Salmonella strains (Typhimurium and Heildelberg) were able to penetrate through the eggshell and spread inside the egg in the albumen and yolk. In addition, the serotype Typhimurium presented higher contamination efficiency and increased resistance against the antimicrobial mechanisms of the albumen. It is worth noting that further studies are required in order to clarify the mechanisms of eggshell penetration and survival of bacteria inside the egg for different Salmonella strains. 


\section{Conflict of Interest}

The authors declare no conflicts of interest.

\section{Ethics Statement}

The author declares that each contribution to this article has been acknowledged and source of information from other peoples' published or unpublished works have been cited referenced. And certify that is solely responsible for

\section{References}

ABPA: Associação Brasileira de Proteína Animal. [Internet]. Relatório Anual 2018. São Paulo: ABPA; 2018 [cited 2018 Nov 22]. Available from: http://abpa-br.com.br/storage/ files/relatorio-anual-2018.pdf

Back A. Manual de doenças de aves. Cascavel: Editora Coluna do Saber; 2004. Doenças bacterianas; p. 57-60

Baron F, Gautier M, Brule G. Factors involved in the Inhibition of growth of Salmonella enteritidis in liquid egg white. J Food Prot. 1997;60(11):1318-23. http://dx.doi. org/10.4315/0362-028X-60.11.1318.

Baron F, Nau F, Guérin-Dubiard C, Bonnassie S, Gautier M, Andrews SC, Jan S. Egg white versus Salmonella Enteritidis! A harsh medium meets a resilient pathogen. Food Microbiol. 2016;53(Pt B):82-93. http://dx.doi.org/10.1016/j. fm.2015.09.009. PMid:26678134.

Berrang ME, Cox NA, Frank JF, Buhr RJ. Bacterial penetration of the eggshell and shell membranes of the chicken hatching egg: a review. J Appl Poult Res. 1999;8(4):499-504. http:// dx.doi.org/10.1093/japr/8.4.499.

Board RG, Loseby S, Miles VR. A note on microbial growth on hen egg-shells. Br Poult Sci. 1979;20(4):413-20. http:// dx.doi.org/10.1080/00071667908416600.

Bruce J, Drysdale EM. Trans-shell transmission. In: Board RG, Fuller R, editors. Microbiology of the avian egg. London: Chapman \& Hall; 1994. p. 63-91 http://dx.doi. org/10.1007/978-1-4615-3060-2_4.

Cardoso TG, Carvalho VM. Toxinfecção alimentar por Salmonella spp. Rev Inst Ciênc Saúde = J Health Sci Inst 2006;24(2):95-101.

Carrique-Mas JJ, Marín C, Breslin M, Mclaren I, Davies R. A comparison of the efficacy of cleaning and disinfection text of the article and work included in the article along with any incomplete reference

\section{Acknowledgements}

The authors gratefully acknowledge the financial institutions CNPq Bolsa PIBIC and SEG / Embrapa Project (03.13.10.005) for funding research.

methods in eliminating Salmonella spp. from commercial egg laying houses. Avian Pathol. 2009;38(5):419-24. http:// dx.doi.org/10.1080/03079450903193768. PMid:19937529.

Chousalkar KK, Flynn P, Sutherland M, Roberts JR, Cheetham BF. Recovery of Salmonella and Escherichia coli from commercial egg shells and effect of translucency on bacterial penetration in eggs. Int J Food Microbiol. 2010;142(1-2):20713. http://dx.doi.org/10.1016/j.ijfoodmicro.2010.06.029. PMid:20663580.

Clements M. [Internet]. Who are the world's largest egg producers? Rockford: WATTAgNet; 2015 [cited 2018 Feb 10]. Available from: https://www.wattagnet.com/articles/20682who-are-the-world-s-largest-egg-producers.

Cockburn W, Vemon E. Food poisoning in England and Wales 1956. Mon Bull Minist Health Public Health Lab Serv. 1956; 233-241.

Cogan TA, Jørgensen F, Lappin-Scott HM, Benson CE, Woodward MJ, Humphrey TJ. Flagella and curli fimbriae are important for the growth of Salmonella enterica serovars in hen eggs. Microbiology. 2004;150(4):1063-71. http:// dx.doi.org/10.1099/mic.0.26791-0. PMid:15073315.

Conmay A. World egg output grows despite disease impact. Poultry Trends. 2015; p. 28-35

Cuttell L, Groves M, Wilson A. Microbiological baseline survey of the Queensland egg production environment. Brisbane: Queensland; 2014.

De Reu K, Grijspeerdt K, Messens W, Heyndrickx M, Uyttendaele M, Debevere J, Herman L. Eggshell factors influencing eggshell penetration and whole egg contamination by different bacteria, including Salmonella Enteritidis. Int J Food Microbiol. 2006;112(3):253-60. http://dx.doi. org/10.1016/j.ijfoodmicro.2006.04.011. PMid:16822571. 
Denagamage T, Jayarao B, Patterson P, Wallner-Pendleton E, Kariyawasam S. Risk factors associated with Salmonella in laying hen farms: systematic review of observational studies. Avian Dis. 2015;59(2):291-302. http://dx.doi. org/10.1637/10997-120214-Reg. PMid:26473681.

Foley SL, Nayak R, Hanning IB, Johnson TJ, Han J, Ricke SC. Population dynamics of Salmonella enterica serotypes in commercial egg and poultry production. Appl Environ Microbiol. 2011;77(13):4273-9. http://dx.doi.org/10.1128/ AEM.00598-11. PMid:21571882.

Gantois I, Ducatelle R, Pasmans F, Haesebrouck F, Gast R, Humphrey TJ, Van Immerseel F. Mechanisms of egg contamination by Salmonella Enteritidis. FEMS Microbiol Rev. 2009;33(4):718-38. PMid:19207743. https://doi. org/10.1111/j.1574-6976.2008.00161.x

Garber L, Smeltzer M, Fedorka-Cray P, Ladely S, Ferris K. Salmonella enterica Serotype enteritidis in table egg layer house environments and in mice in U.S. Layer Houses and associated risk factors. Avian Dis. 2003;47(1):134-42. http://dx.doi.org/10.1637/0005-2086(2003)047[0134:SES EIT]2.0.CO;2. PMid:12713168.

Gast RK, Holt PS. Deposition of Phage Type 4 and 13a Salmonella enteritidis strains in the yolk and albumen of eggs laid by experimentally infected hens. Avian Dis. 2000;44(3):706-10. http://dx.doi.org/10.2307/1593116. PMid:11007024.

Gast RK, Holt PS. Assessing the frequency and consequences of Salmonella enteritidis deposition on the egg yolk membrane. Poult Sci. 2001;80(7):997-1002. http://dx.doi.org/10.1093/ ps/80.7.997. PMid:11469668.

Gast RK, Guard-Petter J, Holt PS. Effect of prior serial in vivo passage on the frequency of Salmonella enteritidis contamination in eggs from experimentally infected laying hens. Avian Dis. 2003;47(3):633-9. http://dx.doi. org/10.1637/6098. PMid:14562891.

Gast RK, Holt PS, Murase T. Penetration of Salmonella Enteritidis and Salmonella Heidelberg into egg yolks in an in vitro contamination model. Poult Sci. 2005;84(4):621-5. http://dx.doi.org/10.1093/ps/84.4.621. PMid:15844820.

Gast RK, Holt PS, Guraya R. Effect of refrigeration on in vitro penetration of Salmonella Enteritidis through the egg yolk membrane. J Food Prot. 2006;69(6):1426-9. http:// dx.doi.org/10.4315/0362-028X-69.6.1426. PMid:16786867.
Gast RK, Guraya R, Guard-Bouldin J, Holt PS. In vitro penetration of egg yolks by Salmonella Enteritidis and Salmonella Heidelberg strains during thirty-six-hour ambient temperature storage. Poult Sci. 2007;86(7):1431-5. http://dx.doi.org/10.1093/ps/86.7.1431. PMid:17575192.

Gast RK, Jones DR, Anderson KE, Guraya R, Guard J, Holt PS. In vitro penetration of Salmonella Enteritidis through yolk membranes of eggs from 6 genetically distinct commercial lines of laying hens. Poult Sci. 2010;89(8):1732-6. http:// dx.doi.org/10.3382/ps.2009-00440. PMid:20634530.

Gole VC, Caraguel CGB, Sexton M, Fowler C, Chousalkar KK. Shedding of Salmonella in single age caged commercial layer flock at an early stage of lay. Int J Food Microbiol. 2014;189:616. http://dx.doi.org/10.1016/j.ijfoodmicro.2014.07.030. PMid:25123093.

Gould LH, Walsh KA, Vieira AR, Herman K, Williams IT, Hall AJ, Cole D. Surveillance for foodborne disease outbreaks - United States, 1998-2008. MMWR Surveill Summ. 2013;62(2):1-34. PMid:23804024.

Guan J, Grenier C, Brooks BW. In vitro study of Salmonella Enteritidis and Salmonella Typhimurium DT104: survival in egg albumen and penetration through the vitelline membrane. Poul Sci. 2006;85(9):1678-81. http://dx.doi.org/10.1093/ps/85.9.1678

Gurtler JB, Conner DE. Survival and growth of Salmonella Enteritidis in liquid egg products varying by temperature, product composition, and carbon dioxide concentration. Foodborne Pathog Dis. 2009;6(5):561-7. http://dx.doi. org/10.1089/fpd.2008.0202. PMid:19388831.

Hennessy TW, Har Cheng L, Kassenborg H, Ahuja SD, Mohle-Boetani J, Marcus R, Shiferaw B, Angulo FJ. Egg consumption is the principal risk factor for sporadic Salmonella serotype Heidelberg infections: a case-control study in FoodNet sites. Clin Infect Dis. 2004;38(Suppl 3):S237-43. http://dx.doi.org/10.1086/381593. PMid:15095195.

Howard ZR, O'Bryan CA, Crandall PG, Ricke SC. Salmonella Enteritidis in shell eggs: current issues and prospects for control. Food Res Int. 2012;45(2):755-64. http://dx.doi. org/10.1016/j.foodres.2011.04.030.

Hughey VL, Johnson EA. Antimicrobial activity of lysozyme against bacteria involved in food spoilage and food-borne disease. Appl Environ Microbiol. 1987;53(9):2165-70. PMid:3118808. 
Humphrey TJ, Greenwood M, Gilbert RJ, Rowe B, Chapman PA. The survival of salmonellas in shell eggs cooked under simulated domestic conditions. Epidemiol Infect. 1989;103(1):35-45. http://dx.doi.org/10.1017/ S0950268800030338. PMid:2673824.

Humphrey TJ, Whitehead A, Gawler AHL, Henley A, Rowe B. Numbers of Salmonella Enteritidis in the contents of naturally contaminated hens' eggs. Epidemiol Infect. 1991;106(3):489-96. http://dx.doi.org/10.1017/ S0950268800067546. PMid:2050203.

Huneau-Salaün A, Marianne C, Sophie B, Françoise L, Isabelle P, Sandra R, Virginie M, Philippe F, Nicolas R. Risk factors for Salmonella enterica subsp. enterica contamination in 519 French laying hen flocks at the end of the laying period. Prev Vet Med. 2009;89(1-2):51-8. http://dx.doi. org/10.1016/j.prevetmed.2009.01.006. PMid:19237216.

Im MC, Jeong SJ, Kwon YK, Jeong O-M, Kang M-S, Lee YJ. Prevalence and characteristics of Salmonella spp. isolated from commercial layer farms in Korea. Poult Sci. 2015;94(7):1691-8. http://dx.doi.org/10.3382/ps/pev137. PMid:26015591.

Jackson BR, Griffin PM, Cole D, Walsh KA, Chai SJ. Outbreak-associated Salmonella enterica serotypes and food commodities, United States, 1998-2008. Emerg Infect Dis. 2013;19(8):1239-44. http://dx.doi.org/10.3201/ eid1908.121511. PMid:23876503.

Kinde H, Castellan DM, Kerr D, Campbell J, Breitmeyer $\mathrm{R}$, Ardans A. Longitudinal monitoring of two commercial layer flocks and their environments for Salmonella enterica serovar Enteritidis and other Salmonellae. Avian Dis. 2005;49(2):189-94. http://dx.doi.org/10.1637/7228-062704R. PMid:16094821.

Lapuz RRSP, Umali DV, Suzuki T, Shirota K, Katoh H. Comparison of the prevalence of Salmonella infection in layer hens from commercial layer farms with high and low rodent densities. Avian Diseases Digest. 2012;56(1):2934. http://dx.doi.org/10.1637/9998-970411-DIGEST.1. PMid:22545525.

Li X, Payne JB, Santos FB, Levine JF, Anderson KE, Sheldon BW. Salmonella populations and prevalence in layer feces from commercial high-rise houses and characterization of the Salmonella isolates by serotyping, antibiotic resistance analysis, and pulsed field gel electrophoresis. Poult Sci. 2007;86(3):591-7. http://dx.doi.org/10.1093/ps/86.3.591. PMid:17297173.
Lu S, Killoran PB, Riley LW. Association of Salmonella enterica serovar enteritidis YafD with resistance to chicken egg albumen. Infect Immun. 2003;71(12):6734-41. http://dx.doi. org/10.1128/IAI.71.12.6734-6741.2003. PMid:14638758.

Martelli F, Davies RH. Salmonella serovars isolated from table eggs: an overview. Food Res Int. 2012;45(2):745-54. http://dx.doi.org/10.1016/j.foodres.2011.03.054.

Messens W, Duboccage L, Grijspeerdt K, Heyndrickx M, Herman L. Growth of Salmonella serovars in hens' egg albumen as affected by storage prior to inoculation. Food Microbiol. 2004;21(1):25-32. http://dx.doi.org/10.1016/ S0740-0020(03)00045-5.

Messens W, Grijspeerdt K, Herman L. Eggshell penetration of hen's eggs by Salmonella enterica serovar Enteritidis upon various storage conditions. Br Poult Sci. 2006;47(5):55460. http://dx.doi.org/10.1080/00071660600954601. PMid:17050098.

Miyamoto T, Baba E, Tanaka T, Sasai K, Fukata T, Arakawa A. Salmonella Enteritidis contamination of eggs from hens inoculated by vaginal, cloacal and intravenous routes. Avian Dis. 1997;41(2):296-303. http://dx.doi.org/10.2307/1592181. PMid:9201391.

Mollenhorst H, Van Woudenbergh CJ, Bokkers EGM, De Boer IJM. Risk factors for Salmonella enteritidis infections in laying hens. Poult Sci. 2005;84(8):1308-13. http://dx.doi. org/10.1093/ps/84.8.1308. PMid:16156216.

Muriana, PM. Effect of $\mathrm{pH}$ and hydrogen peroxide on heat inactivation of Salmonella and Listeria in egg white. Food Microbiol. 1997;14:11-19. https://doi.org/10.1006/ fmic. 1996.0068

Namata H, Méroc E, Aerts M, Faes C, Abrahantes JC, Imberechts H, Mintiens K. Salmonella in Belgian laying hens: an identification of risk factors. Prev Vet Med. 2008;83(34):323-36. http://dx.doi.org/10.1016/j.prevetmed.2007.09.002. PMid:17961763.

NSW: New South Wales. Department of Primary Industries. NSW poultry egg industry overview 2015. Paterson: NSW 2015.

Oliveira DD, Silva EN. Salmonella em ovos comerciais: ocorrência, condições de armazenamento e desinfecção da casca. Arq Bras Med Vet Zootec. 2000;52(6):655-61. http:// dx.doi.org/10.1590/S0102-09352000000600017. 
The OzFoodNet Working Group. Foodborne disease in Australia: incidence, notifications and outbreaks. annual report of the OzFoodNet Network, 2002. Commun Dis Intell. 2003;27(2):164-90.

The OzFoodNet Working Group. Enhancing foodborne disease surveillance across Australia in 2001. Commun Dis Intell. 2002;26(3):375-406.

The OzFoodNet Working Group. Reported foodborne illness and gastroenteritis in Australia: annual report of the OzFoodNet Network, 2004. Commun Dis Intell. 2005:29(2):164-90.

The OzFoodNet Working Group. Burden and Causes of foodborne disease in Australia: annual report of the OzFoodNet Network, 2005, Branch. Commun Dis Intell. 2006;30(3):278-300.

The OzFoodNet Working Group. Monitoring the incidence and causes of diseases potentially transmitted by food in Australia: annual report of the Ozfoodnet Network, 2010. Commun Dis Intell. 2012:30(3):E213-41.

Padron M. Salmonella typhimurium penetration through the eggshell of hatching eggs. Avian Dis. 1990;34(2):463-5. http://dx.doi.org/10.2307/1591437. PMid:2196048.

Painter JA, Hoekstra RM, Ayers T, Tauxe RV, Braden CR, Angulo FJ, Griffin PM. Attribution of foodborne illnesses, hospitalizations, and deaths to food commodities by using outbreak data, United States, 1998-2008. Emerg Infect Dis. 2013;19(3):407-15. http://dx.doi.org/10.3201/eid1903.111866. PMid:23622497.

Pitesky M, Charlton B, Bland M, Rolfe D. Surveillance of Salmonella Enteritidis in layer houses: a retrospective comparison of the food and drug administration's egg safety rule (2010-2011) and the California Egg Quality Assurance Program (2007-2011). Avian Dis. 2013;57(1):51-6. http:// dx.doi.org/10.1637/10281-061312-Reg.1. PMid:23678729.

Poppe C, Ducan CL, Mazzocco A. Salmonella contamination of hatching and table eggs: a comparison. Can J Vet Res. 1998;(62):191-98. PMID: 9684048.

Raghiante F, Rocha TS, Rossi DA, Silva PL. Penetration time of Salmonella Heidelberg through shells of white and brown commercial eggs. Rev Bras Cienc Avic. 2010;12(4):273-7. http://dx.doi.org/10.1590/S1516-635X2010000400009.
Ray A, Roberts JR, Flavel R, Chousalkar KK. Eggshell penetration by Salmonella Typhimurium in table eggs: examination of underlying eggshell structures by microcomputed tomography and scanning electron microscopy. Food Res Int. 2015;78:34-40. http://dx.doi.org/10.1016/j. foodres.2015.11.010. PMid:28433301.

Reddy SP, Wang H, Adams JK, Feng PCH. Prevalence and characteristics of Salmonella serotypes isolated from fresh produce marketed in the United States. J Food Prot. 2016;79(1):6-16. http://dx.doi.org/10.4315/0362-028X. JFP-15-274. PMid:26735024.

Ricke SC, Gast RK. Producing safe eggs: microbial ecology of Salmonella. Elsevier: London; 2016. 431 p.

SAS Institute Inc. System for Microsoft Windows, Release 9.4. [CD-ROM]. Cary: SAS Institute Inc.; 2012.

Schoeni JL, Glass KA, McDermott JL, Wong AC. Growth and penetration of Salmonella enteritidis, Salmonella heidelberg and Salmonella typhimurium in eggs.. Int J Food Microbiol. 1995;24(3):385-96. http://dx.doi.org/10.1016/01681605(94)00042-5. PMid:7710915.

Snow LC, Davies RH, Christiansen KH, Carrique-Mas JJ, Cook AJC, Evans SJ. Investigation of risk factors for Salmonella on commercial egg-laying farms in Great Britain, 2004-2005. Vet Rec. 2010;166(19):579-86. http:// dx.doi.org/10.1136/vr.b4801. PMid:20453235.

Sparks NH, Board RG. Bacterial penetration of the recently oviposited shell of hens' eggs. Aust Vet J. 1985;62(5):16970. http://dx.doi.org/10.1111/j.1751-0813.1985.tb07281.x. PMid:4038226.

Strawn LK, Danyluk MD, Worobo RW, Wiedmann M. Distributions of Salmonella subtypes differ between two U.S. produce-growing regions. Appl Environ Microbiol. 2014;80(13):3982-91. http://dx.doi.org/10.1128/AEM.0034814. PMid:24747908.

Thomas C, Daughtry B, Padula D, Jordan D, Arzey G, Davey K, Holds G, Slade J, Pointon A. An egg: Salmonella quantitative risk assessment model for the Australian Egg Industry. Sydney: Australian Egg Corporation Limited; 2006.

Todd EC. Risk assessment of use of cracked eggs in Canada. Int J Food Microbiol. 1996;1996(30):125-43. http://dx.doi. org/10.1016/0168-1605(96)00995-6. PMid:8856379. 
Van Hoorebeke S, Van Immerseel F, De Vylder J, Ducatelle R, Haesebrouck F, Pasmans F, De Kruif A, Dewulf J. The age of production system and previous Salmonella infections in laying hen flocks. Poult Sci. 2010;89(6):1315-9. http:// dx.doi.org/10.3382/ps.2009-00532. PMid:20460679.

Wallner-Pendleton EA, Patterson PH, Kariyawasam S, Trampel DW, Denagamage T. On-farm risk factors for Salmonella Enteritidis contamination1. J Appl Poult Res. 2014;23(2):345-52. http://dx.doi.org/10.3382/japr.2014-00943.

Williams JE, Dillard LH, Hall GO. The penetration patterns of Salmonella the outer structures of chicken eggs. Avian Dis. 1968;12:445-6. http://dx.doi.org/10.2307/1588161. PMid:4879637.
Financial institutions (grants and scholarships): $\mathrm{CNPq}$ Brazil, PIBIC scholarship (research execution) and SEG/Embrapa Project, Brazil (03.13.10.005) (research execution, manuscript preparation, design of the research study); collection, analysis, and interpretation of data; article writing; journal selection and submission.

Authors Contributions: Germana Vizzotto Osowski, Sabrina Castilho Duarte, Lana Flávia Baron, and Roberto Degenhardt carried out the experiment. Germana Vizzotto Osowski wrote the manuscript with support from Sabrina Castilho Duarte, Lana Flávia Baron, Arlei Codebella, Francisco Noé Fonseca, Roberto Degenhardt and Sandra Camile Almeida Mota helped supervise the project. Sabrina Castilho Duarte conceived the original idea and supervised the project. 